організувати навчання в необхідному для студента темпі і на доступному для нього рівні. Сучасні ТЗН на базі комп'ютера сприяють також оволодінню навичками іншомовного письма, вправлянню в граматиці і орфографії з автоматичним контролем з боку спеціальних програм.

Нині комп'ютер під час навчання іноземних мов $є$ також технічним засобом міжособистісного спілкування на основі багатофункціональних мережних мультимедійних навчальних комплексів і автоматизованих навчальних систем. Такі комплекси й системи мають універсальні дидактичні можливості, дозволяють вести навчання в діалоговому режимі з урахуванням індивідуальних можливостей тих, хто навчається; забезпечують вилучене навчання з використанням сучасних технологій [5, c. 17].

Отже, зроблений нами огляд найбільш розповсюджених ТЗН іноземній мові відображає досить значні позитивні моменти. Залежно від дидактичного призначення ТЗН можуть бути використані: як джерела іншомовних знань, як засіб організації самостійної роботи, як засіб унаочнення, вправляння, повторення та систематизації іншомовних знань за всіма видами мовленнєвої діяльності. Сучасні різновиди ТЗН застосовуються як окремо, так і комплексно, одночасно або послідовно поєднуючи різні за технічними, навчальними, розвивальними і виховними можливостями засоби під час виконання студентами вправ, що передують поясненню, у ході пояснення, тренування, повторення і закріплення навчального матеріалу. Сучасні ТЗН на базі комп'ютера повною мірою здатні компенсувати й змоделювати природне іншомовне середовище для індивідуального й диференційованого навчання іноземної мови відповідно до навчальних досягнень і рівня пізнавального інтересу і професійних потреб студентів. Дидактично правильне використання ТЗН уможливлює інтенсифікацію навчання іноземних мов завдяки граничному навантаженню мовного i слухового каналу тих, хто навчається, активізації їх розумової і мовленнєвої діяльності, оптимізації пізнання міжкультурних та іншомовних явищ.

\title{
Література
}

1. Волкова Н. П. Педагогіка / Наталія Павлівна Волкова. - К. : Академія, 2001. 576 с. 2. Зимняя И. А. ТСО и наглядность в обучении иностранному языку / Ирина Александровна Зимняя. - М. : Педагогика, 1979. - 310 с. З. Ляховицкий М. В. Технические средства в обучении иностранным языкам / М. В. Ляховицкий, И. М. Кошман. - М. : Просвещение, 1981. - 240 с. 4. Методика викладання іноземних мов у середніх навчальних закладах : [підручник]/ Кол. авторів під керів. С. Ю. Ніколаєвої. - К. : Ленвіт, 2002. - 328 с. 5. Полат Е. С. Интернет на уроках иностранного языка / Е. С. Полат // Иностранные языки в школе. - 2001. - № 2-3. С. 15-18. 6. Рожкова Ф. М. Кинофильмы на уроках английского языка / Ф. М. Рожкова. - М. : Просвещение, 1987. - 115 с.

УДК $81 ’ 243: 378.147$

Вікторія Лапіна

\section{ДИДАКТИЧНІ УМОВИ РЕАЛІЗАЦІЇ НАВЧАЛЬНОГО ДІАЛОГУ ПІД ЧАС ВИВЧЕННЯ ІНОЗЕМНИХ МОВ У ТЕХНІЧНИХ ВИШАХ}

Лапіна В. О. Дидактичні умови ефективної реалізації навчального діалогу під час вивчення іноземних мов у технічних вишах.

У статті розглянуто умови ефективного упровадження навчального діалогу в процес вивчення іноземних мов як засобу формування мовленнєвої компетентності студентів технічних спеціальностей, які враховують особливості окресленого процесу 
(іншомовний аспект, професійний контекст та специфіку обраного дидактичного засобу) та сприяють ефективній організації діалогічного навчання на засадах педагогіки співпраці.

Ключові слова: дидактичні умови, навчальний діалог, іншомовна професійно зорієнтована мовленнєва компетентність.

Лапина В. О. Дидактические условия эффективной реализации учебного диалога при изучении иностранных языков в технических вузах.

В статье рассмотрены условия эффективного внедрения учебного диалога в процесс изучения иностранных языков как средства формирования речевой компетентности студентов технических специальностей, которые учитывают особенности очерченного процесса (иноязычный аспект, профессиональный контекст и специфику выбранного дидактического средства) и способствуют эффективной организации диалогического обучения на основе педагогики сотрудничества.

Ключевые слова: дидактические условия, учебный диалог, иноязычная профессионально-ориентированная речевая компетентность.

Lapina V. O. Didactic conditions of effective realizing educational dialogue while learning foreign languages in technical higher educational establishments.

The article deals with the didactic conditions of effective implementation of educational dialogue in the process of learning foreign languages as a means of forming speech competence of technical specialties students. These conditions take into account the features of the outlined process (foreign aspect, professional context and the specifics of the chosen didactic means) and allow improving the efficiency of organizing dialogic learning on the bases of pedagogy of cooperation.

Key words: didactic conditions, educational dialogue, foreign professionally oriented speech competence.

3-поміж тенденцій в оновленні освітнього процесу вишу найбільшої уваги заслуговують ті, що зорієнтовані на особистість студента, ураховують його інтереси й потреби, забезпечують успішне виявлення та максимальний розвиток індивідуально значущих позитивних задатків, сприяють вияву суб'єктності педагога та студента в навчальній діяльності. Відтак пріоритетною в навчальній діяльності стає одна 3 провідних стратегій удосконалення професійної мовної підготовки студентів демократизація та гуманізація вищої освіти, орієнтація на формування нової культури взаємодії педагога зі студентами - культури діалогу, основу якого становлять суб'єктсуб'єктні стосунки, що передбачають рівність позицій двох особистостей - викладача та студента, які можуть повною мірою виявити себе як активні рівноправні партнери.

У процесі формування іншомовної професійно зорієнтованої мовленнєвої компетентності студентів - майбутніх гірників навчальний діалог (НД) розглядаємо як ефективний дидактичний засіб накопичення, формування та розвитку суб'єктивних мовленнєвих знань, навичок i вмінь - особистісного мовленнєвого ресурсу (компетентності) через активізацію та реалізацію інтелектуального i творчого потенціалу учасників діалогічної взаємодії у форматі «викладач - студент (студенти)» або «студент - студент (студенти)», спрямованої на розв'язання проблемних навчально-комунікативних ситуацій на заняттях з іноземної мови.

Для максимальної реалізації дидактичного потенціалу навчального діалогу необхідно виокремити чинники, які впливають на ефективність в організації діалогічного навчання на засадах педагогіки співпраці в технічних вишах. 
Отже, метою статmі є дослідження дидактичних умов, які сприяють ефективній реалізації дидактичного потенціалу навчального діалогу як засобу формування мовленнєвої компетентності студентів технічних спеціальностей під час вивчення іноземних мов.

Дидактичні умови - це сукупність обставин, окреслених позицій, вимог, правил, що впливають на функціонування й розвиток певного дидактичного об'єкту, дидактичної системи, моделі, процесу. Із загальних педагогічних напрацювань, висновків, рекомендацій щодо різних комплексів умов цілеспрямовано обираються саме ті, які сприяють досягненню конкретних дидактичних цілей 3 урахуванням специфічних особливостей окремого дидактичного випадку (означеної мети, обраного засобу тощо).

Вибір дидактичних умов зумовлений особливостями обраного дидактичного засобу (навчального діалогу) та специфікою процесу формування мовленнєвої компетентності студентів технічних вишів під час вивчення іноземних мов, тобто іншомовної професійно зорієнтованої мовленнєвої компетентності (ІПЗМК).

Ураховуючи специфічні особливості сучасного діалогічного навчання, стверджуємо, що ефективній реалізації НД як засобу формування та розвитку ІПЗМК студентів сприяє забезпечення суб'єкт-суб'єктної діалогічної взаємодії учасників освітнього процесу, яку ми визначаємо як одну з головних дидактичних умов іншомовної мовленнєвої підготовки студентів технічних ВНЗ.

Провідною характеристикою суб'єкт-суб'єктного навчання $є$ діалогічність навчального процесу, налаштованість його учасників на діалог, що проявляється в толерантності до позиції іншого (відмова від претензій на володіння абсолютною істиною), передбачає діалогічну взаємодію на рівні позицій, а не догм, встановлення особливого морально-психологічного клімату між викладачем і студентом, який характеризується відкритістю, доброзичливістю, взаємною довірою та повагою [8].

Розглядаючи процес формування та розвитку ІПЗМК студентів як паритетну діалогічну взаємодію реального співробітництва та співтворчості викладача та студентів, в основу якої покладено ідеї сучасної гуманістичної парадигми освіти, за якою викладач не стільки транслює студентам доробки культури, скільки культивує їі подальший розвиток у процесі педагогічної творчості, констатуємо, що така навчальна діяльність грунтується на навчально-пізнавальній активності усіх іiі учасників.

Відповідно, ще однією дидактичною умовою ефективної реалізації НД як діалогічної суб'єкт-суб'єктної взаємодії всіх учасників процесу професійномовленнєвої підготовки на заняттях з IM виокремлюємо активізацію пізнавальнопошукової діяльності всіх суб 'єктів.

3-поміж шляхів активізації навчальної діяльності учасників діалогічної взаємодії виокремлюють два основні: через зміст навчального матеріалу й через процес навчання.

Дидактичний зміст сприяє активізації навчального процесу через опрацювання автентичних текстів із проблемним контекстом за фаховою проблематикою, розв'язання яких сприяє виникненню у студентів внутрішніх суперечностей між наявним ресурсом знань і неможливістю виконати поставлені завдання, тим самим стимулює розумово-пошукову діяльність суб'єктів навчання. Окрім того, тексти за фахом є цінним інформаційним та пізнавальним матеріалом, який доповнює отримані студентами під час вивчення спеціальних дисциплін знання; джерелом словникового запасу студентів, прикладом уживання термінологічної лексики у контексті, що допомагає конкретизувати значення слів, пояснити й уточнити випадки їх вживання відповідно до усталених мовних норм і стандартів [5]. 
До способів активізації діяльності суб'єктів діалогічної взаємодії через сам навчальний процес відносять використання активних методів, прийомів та форм навчання, які стимулюють пізнавально-пошукову діяльність та сприяють створенню атмосфери творчості, співробітництва, взаємопідтримки; ситуації успіху: студенти оволодівають знаннями, впевнено долаючи труднощі під час розв'язання завдань, що сприяєдосягненню продуктивної діалогічної суб'єктної взаємодії на заняттях з IM.

Виокремлюють два основні види інтеракції (активної взаємодії) - коопераиія (характеризується об'єднанням зусиль учасників для досягнення спільної мети за одночасного розподілу між ними функцій і створенням позитивної взаємозалежності цілей) та конкуренція (міжособистісна взаємодія, заснована на зіткненні цілей, інтересів, позицій, думок, поглядів іiі суб'єктів, для якої характерна негативна взаємозалежність цілей: учасники розуміють, що можуть досягти своєї мети за умови невдачі свого партнера, їхні успіхи не залежать від товаришів, тому студент або працює ще більш старанно, або відступає, оскільки не впевнений в успіху своїх досягнень) [6].

Переконані, що мобілізація творчого потенціалу суб'єктів діалогічної взаємодії більш ефективно відбувається в кооперативних відносинах. Аналіз наукових праць (Л. Воротняк, Гайдукова, Д. Джонсон, Р. Джонсон, I. Ігнатова, М. Лісовий, О. Пометун, Н. Сура), пов'язаних із дослідженнями моделей кооперативного діалогічного суб'єктного навчання, дозволив виокремити і розглянути саме ті, що сприяють підвищенню пізнавальної активності його учасників та успішній реалізації навчального діалогу на заняттях 3 іноземної мови: активні форми організації кооперативного навчання (в співпраці); ситуативне моделювання; опрацювання дискусійних питань.

Суть усіх активних методів полягає в тому, щоб дати стимул-реакцію для пізнавально-пошукової діяльності та комунікації, щоб студент захотів сам здобувати знання. Але слід зазначити, що для цього недостатньо сформувати групи і дати їм відповідне завдання. Існує вислів мудреців: «Я можу підвести верблюда до водопою, але не можу змусити його напитися!» Отже, проблема мотивації навчальної діяльності студентів є найважливішою умовою ефективної спільної взаємодії в навчанні [3, с. 28].

Важливим чинником, що суттєво впливає на підвищення ефективності процесу формування ІПЗМК студентів технічних ВНЗ, ми вважаємо усвідомлення ними значущості професійного іншомовного мовлення у майбутній фаховій діяльності, якому сприяє висока вмотивованість студентів у цьому процесі. Класичний закон Йеркса-Додсона встановив залежність активності людини від сили мотивації. За цим законом, чим вище сила мотивації, тим краще результативність діяльності [4]. Відповідно, чим вище умотивованість студентів до вивчення IM для професійного спілкування, тим більш високі результати процесу формування навичок та вмінь іншомовного мовлення. Відтак підвищення мотивації студентів до процесу формування іншомовної професійно зорієнтованої мовленнєвої компетентності є ще однією дидактичною умовою реалізації освітнього потенціалу навчального діалогу як засобу формування означеної компетентності.

У педагогіці мотивацію тлумачать по-різному: як один конкретний мотив; як єдину систему мотивів, яка визначає певні форми діяльності або поведінку людини; як сферу, що охоплює потреби, цілі та інтереси особистості у їх складних взаємозв'язках; як систему спонукань, до якої входять потяги, мотиваційні установки, ідеали тощо [7, c. 51, c. 81$]$.

Уважаємо за доцільне виокремити професійну комунікативно зорієнтовану мотивацію, яка враховує специфіку мовної підготовки студентів технічних ВНЗ на 
заняттях з IM, спонукає їх не тільки до активної навчальної діяльності, пов'язаної 3 отриманням фахових знань, але й відповідає за їхню внутрішню вмотивованість до опанування необхідними мовними, мовленнєвими та комунікативними компетенціями (компетентностями) для реалізації ефективного спілкування іноземною мовою в майбутній професійній діяльності. Нас цікавить не просто вмотивованість студентів у загальній професійній підготовці, а прагнення студентів до активної навчальної діяльності на заняттях 3 IM, спрямованої на формування їхньої іншомовної професійно зорієнтованої мовленнєвої компетентності, необхідної для продуктивної професійної комунікації у майбутньому фаховому середовищі. Саме цим пояснюється необхідність виокремлення комунікативно зорієнтованої мотивації як різновиду професійної.

Щоб залучити студентів технічних ВНЗ до активного вивчення іноземної мови задля формування ІПЗМК, необхідно довести, що мова $\epsilon$ ефективним засобом їхньої професійної реалізації в майбутньому, тобто переконати в практичній цінності навчання іноземної мови. Цьому сприяє високий рівень сформованості внутрішньої навчальної (пізнавально-пошукової) та професійної (комунікативно зоріснтованої) мотиваціï.

Отже, стверджуємо, що окреслені вище дидактичні умови (забезпечення суб'єктсуб'єктної діалогічної взаємодії учасників освітнього процесу; активізація пізнавально-пошукової діяльності суб'єктів діалогічного навчання та підвищення мотивації студентів до процесу формування іншомовної професійно зорієнтованої мовленнєвої компетентності) дозволять досягнути найвищого рівня реалізації можливостей НД у процесі формування ІПЗМК студентів, оскільки за таких умов діалог $\epsilon$ дійсно обміном інформації (змісту культури), а не насадженням «правильних» позицій, знання трактуються як частина культури, а не репродуктивне відтворення прочитаного матеріалу, має місце взаємодоповнення думок, а не орієнтир на «єдино правильну» відповідь, викладач спонукає студентів мислити, критично оцінювати, мотивувати, використовуючи при цьому опосередковані механізми управління (ініціювання, структурування, мотивацію, міжособистісні відносини, мораль, м'яке регулювання тощо) [2].

\section{Література}

1. Бакум 3.П. Теоретико-методичні засади навчання фонетики української мови в гімназії : [монографія] / Зінаїда Павлівна Бакум. - Кривий Ріг : Видавничий дім, 2008. - 338 с. 2. Бондаревская Е. В., Кульневич С. В. Педагогика : личность в гуманистических теориях и системах воспитания : учеб. пособие [для педвузов]/ Е. В. Бондаревская. - М. - Ростов н/Д, 1999. - 560 с. З. Венедиктова С. Л. Проектная деятельность учащихся на уроках немецкого языка/ С. Л. Венедиктова // Иностранные языки в школе. - 2002. - № 1. - С. 25-29. 4. Грабовська Т. Формування позитивної мотивації діяльності особистості /Т. Грабовська, О. Киричук // Рідна школа. - 2002. - № 4. - С. 12-14. 5. Крат О. І. Компоненти системи навчання іноземної мови професійного спрямування через зміст професійної діяльності/ О. І. Крат // Вісник Дніпропетровського університету імені Альфреда Нобеля. - Серія «Педагогіка і психологія». - 2011. - № 2 (2). - С. 69-74. 6. Методика интенсивного обучения иностранным языкам : [учеб. пособ.] ; под. ред. В. А. Бухбиндера, Г. А. Китайгородской. - К. : Высшая школа, 1988. - 343 с. 7. Молодий науковець ХХІ століття : матеріали Всеукраїнської науково-практичної конференції (Кривий Ріг, 5 квітня 2012 р.)/ Міністерство освіти і науки, молоді та спорту України, ДВНЗ «Криворізький національний університет» ; за ред. 3. П. Бакум. - Кривий Ріг : СПД Залозний В. В., 2012. - 340 с. 8. Олійник П. М. Дидактичні принципи навчання та їх 
дидактико-методичні особливості / П. М. Олійник // Методика навчання і наукових досліджень у вищій школі / С. У. Гончаренко, П. М. Олійник, В. К. Федорченко та ін. ; за ред. С. У. Гончаренка, П. М. Олійника. - К. : Вища шк., 2003. - С. 55-68.

УДК 514:371.3

Ірина Молдован

\section{ДО ПИТАННЯ КЛАСИФІКАЦІЇ ГЕОМЕТРИЧНИХ УМІНЬ В УМОВАХ ЗАСТОСУВАННЯ МУЛЬТИМЕДІЙНИХ ЗАСОБІВ}

Молдован I. В. До питання класифікації геометричних умінь в умовах застосування мультимедійних засобів навчання.

У статті з'ясовано питання класифікації геометричних умінь, зокрема потребу у iii конкретизації, в умовах застосування мультимедійних засобів навчання. Автор пропонує виокремлено уміння, пов'язані 3 роботою 3 мультимедійною дошкою, проекційною системою, у програмах пакету Microsoft Office та уміння, які формуються під час роботи із спеціальними навчальними програмами 3 геометрії. 3'ясовано, що мультимедійними засобами можна і доцільно формувати всі групи геометричних умінь. На прикладі фрагменту мультимедійної презентації показано можливості мультимедійного засобу у формуванні в учнів семіотичних умінь на уроці геометрії.

Ключові слова: класифікація умінь учнів, геометричні уміння, мультимедійні засоби навчання, мультимедійна презентація, навчання геометрії.

Молдован И. В. К вопросу о классификации геометрических умений в условиях применения мультимедийных средств обучения.

В статье раскрывается вопрос классификации геометрических умений, в частности выясняется потребность в ее конкретизации в условиях применения мультимедийных средств обучения. Автор предлагает выделять умения, связаные с работой с мультимедийной доской, проекционной системой, в программах пакета Microsoft Office и умения, которые формируются во время работы со специальными учебными программами по геометрии. Выяснено, что мультимедийными средствами можно и целесообразно формировать все группы геометрических умений. На примере фрагмента мультимедийной презентации показаны возможности мультимедийного средства в формировании у учащихся семиотических умений на уроке геометрии.

Ключевые слова: классификация умений учащихся, геометрические умения, мультимедийные средства обучения, мультимедийная презентация, обучение геометрии.

Moldovan I. V. The problem of the geometric skills classification in terms of the multimedia tools usage.

The article deals with the issue of geometric skills classification, in particular, it clarifies the necessity of its specification in the terms of multimedia tools usage. The author suggests to distinguish the skills related to the multimedia whiteboard functioning and the projection system in the programs of Microsoft Office and the skills, which are formed during the work with the special educational programs on geometry. It is cleared up that all groups of geometric skills can be formed with the help of the multimedia means. By the example of the fragment of the multimedia presentation the possibility of multimedia tools in formation of the pupils' semiotic skills at the geometry lesson are shown.

Key words: classification of pupils' skills, geometric skills, multimedia tools, 